artelogie

\section{Artelogie}

Recherche sur les arts, le patrimoine et la littérature de l'Amérique latine

\section{$4 \mid 2013$}

Fêtes et célébrations en Amérique latine

\title{
A festa da Pátria : Memórias cívicas na área rural de Novo Hamburgo/RS (1930-1970)
}

José Edimar de Souza

\section{OpenEdition \\ Journals}

Edição electrónica

URL: https://journals.openedition.org/artelogie/6416

DOI: $10.4000 /$ artelogie.6416

ISSN: 2115-6395

\section{Editora}

Association ESCAL

\section{Refêrencia eletrónica}

José Edimar de Souza, «A festa da Pátria : Memórias cívicas na área rural de Novo Hamburgo/RS (1930-1970)», Artelogie [Online], 4 | 2013, posto online no dia 02 fevereiro 2013, consultado o 01 dezembro 2021. URL: http://journals.openedition.org/artelogie/6416 ; DOI: https://doi.org/10.4000/ artelogie.6416

Este documento foi criado de forma automática no dia 1 dezembro 2021.

Association ESCAL 


\section{A festa da Pátria : Memórias cívicas na área rural de Novo Hamburgo/RS (1930-1970)}

José Edimar de Souza

\section{Introdução}

1 A Festa da Pátria ${ }^{1}$, ou seja, a festa em comemoração ao Dia da Independência ${ }^{2}$, no Brasil, configura-se como uma das festividades mais expressivas em todos os lugares do país. Em Novo Hamburgo, não é diferente, além disso, a escola é a principal responsável pela mobilização dos sujeitos para, talvez o evento mais esperado do ano pelos escolares - o desfile de sete de setembro como é tradicionalmente conhecido. O sete de setembro é feriado nacional estipulado por lei. Caracteriza-se como um feriado civil pela Lei Federal nº. 9093/95 (com as alterações dadas pela lei nº 10.607 de 2002).

2 Novo Hamburgo é um município do Estado Brasileiro do Rio Grande do Sul. Localiza-se no Vale dos Sinos, distando aproximadamente 50 quilômetros da capital Porto Alegre, tem sua estrutura político-econômica desenvolvida, principalmente, no século XIX, com a chegada dos imigrantes alemães na região. (SOUZA, 2012).

O município, em destaque na figura 1 ocupa uma área de $222,35 \mathrm{~km}^{2}$ e tem uma população de aproximadamente 258.000 habitantes. Limita-se com Campo Bom, Dois Irmãos, Estância Velha, Gravataí, Ivoti, São Leopoldo, Sapiranga, Sapucaia do Sul e Taquara. Em 1985, o Plano Diretor Municipal definiu um perímetro urbano para Lomba Grande de 3,5 km², localizado na região central e uma área rural de 148,3 km². (Schütz, 2001). 


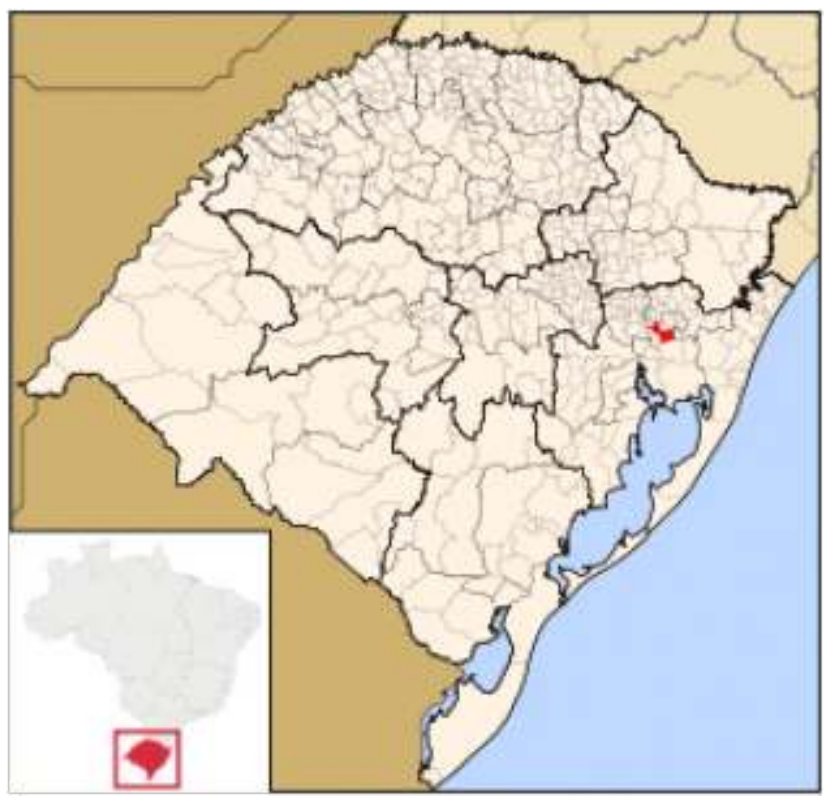

Fonte : SOUZA, 2012.

Em Novo Hamburgo, tradicionalmente acontece o desfile cívico em Lomba Grande, um bairro rural deste município gaúcho, geralmente ocorre no domingo que antecede o feriado. A tradição e culto à festa da Pátria no lugar, talvez esteja associada ao fato de Lomba Grande ter sido Distrito de São Leopoldo e posteriormente de Novo Hamburgo antes de transformar-se em bairro.

O bairro é um espaço dinâmico em que se constroem progressivas aprendizagens estabelecidas nas relações de convivência que cada sujeito desenvolve. (CERTAU, 2011). Investigar como o sentimento nacional foi cultuado e preservado em Lomba Grande é uma forma de contribuir para compreensão das representações que os sujeitos apropriaram e/ou incorporaram em seus discursos sobre a Festa da Pátria, o civismo e o nacionalismo.

Do ponto de vista histórico, Lomba Grande pode ser entendido como um "entre lugar" considerando que desde o século XIX, torna-se um espaço que acolheu um número significativo de imigrantes alemães e configurou-se com "corpus" próprio sem vinculação direta com a Colônia de São Leopoldo. A adversidade do lugar e as condições precárias imprimiram a necessidade da constituição de práticas culturais locais. (BHABHA, 1998).

7 Uma condição de entre lugar indica que entre um nem isto e nem aquilo, há um conjunto de condicionantes que produzem um modo de ser da cultura local. Ou seja, trata-se de percorrer os entre lugares para perceber a tessitura das margens. Isso significa um trabalho que busca compreender como a cultura se fez e, qual sua forma de se tornar presente no cotidiano, ou seja, de como a cultura local estabelece sua pedagogia, como cria seu mundo, encontro de culturas. (THUM, 2009, p. 108).

Partindo dessa relação entre passado e presente, a investigação do cotidiano revelou Lomba Grande como um espaço que não se definiu apenas pela sua configuração física, mas antes pelas ocupações múltiplas que deslocalizaram/relocalizaram suas referências, filiações e identidades. Constituindo-se de um tempo que não diz respeito à 
sequência organizada de situações, mas sim à apropriação pessoal ou coletiva de um conjunto de coordenadas que nos situam face ao devir histórico. (MONARCHA, 2005).

\section{Escolhas teóricas e metodológicas}

Os estudos que envolvem a História Cultural como campo metodológico abrigam diferentes correntes historiográficas e campos temáticos de investigação. Pesavento (2008) complementa esse argumento enfatizando o estudo do passado como um exercício de leitura e interpretação que recupera a ação dos homens no tempo.

o homem torna o tempo um componente humano e elabora redes de significados que traduzem formas de representar o mundo e compartilhar a realidade social. Dessa forma, a história é habitada pelo recorte espaço-temporal que é definido pelo historiador ; pelas relações que estabelece atribuindo sentido inédito às palavras/ imagens que arranca do silêncio dos arquivos. Para Pesavento (2008), pensar o passado, tentar reconstruir e, sobretudo compreender como os homens de outra época davam sentido ao mundo, como se relacionavam e significavam suas práticas sociais, propor enredos, supor desfechos e compor tramas é uma das atribuições daqueles que pretendem se tornar um historiador.

11 Esta prática "[...] reintroduz existências e singularidades no discurso histórico". (CHARTIER, 2002, p. 9). É nessa medida que a preocupação com a experiência humana e o comportamento, valores que são aceitos em uma sociedade e que são rejeitados em outra, adquirem sentido pelas "lentes" do historiador, sendo o "[...] banco de memória da experiência. Teoricamente, o passado - todo o passado, toda e qualquer coisa que aconteceu até hoje, constituí a história". (HOBSBAWM, 2000, p. 37). A História é uma construção da experiência do passado, que tem se realizado em todas as épocas. [...] Inventa o mundo, dentro de um horizonte de aproximações com a realidade. [...] 0 historiador é aquele que, a partir dos traços deixados pelo passado, vai em busca da descoberta do como aquilo teria acontecido, processo este que envolve urdidura, montagem, seleção, recorte, exclusão, ou seja, o historiador cria o passado [...]. (PESAVENTO, 2004, p. 53-54).

12 A memória, utilizada como documento, é entendida no sentido que trata Nora (1993), sendo essa uma fonte para a história. Ao diferenciar a memória como história vivida e história como produção intelectual, o mesmo autor afirma que história e memória não são sinônimos, pois "a memória é a vida carregada por um grupo em permanente evolução, aberta à dialética. A história é a reconstrução sempre problemática do passado, demanda análise e discurso crítico". (NORA, 1993, p. 9). Compartilha-se, da mesma forma, as ideias de Tedesco (2002), que compreende as memórias como atos de evocação do passado, atos que se reestruturam em imagens mentais a partir de arquivos, imagens, fotografias, entrevistas, pois o passado, enquanto tal, não volta, mas a história pode ser recomposta a partir desses artefatos culturais. Assim, a memória, não sendo a História, é um dos indícios, documentos de que se serve o historiador para produzir leituras do passado, do vivido pelos indivíduos, daquilo de que se lembram e se esquecem a um só tempo, produzindo, no presente, determinadas versões do passado. 
13 A memória é também coletiva, isto é, o sujeito tem uma posição individual dos fatos vividos, mas ela se dá pela interação entre os membros da comunidade mais ampla e as experiências vivenciadas entre eles. (HALBWACHS, 2006).

14 A proposta deste estudo é reconstruir fragmentos que permitam compreender como o nacionalismo cívico foi cultuado pelas instituições escolares no espaço rural, principalmente a partir de alguns aspectos da trajetória de duas professoras, verificando assim, como as práticas são reapresentadas pelas narrativas orais que emergiram de sua memória. Neste sentido, optou-se pela entrevista semiestruturada utilizando-se da metodologia da História Oral. Utilizou-se essa modalidade de entrevista a partir de um roteiro com dez questões que privilegiaram memórias das práticas rememoradas de suas trajetórias docentes. (TRIVIÑOS ; NETO ; GIL, 2004). Inicialmente ${ }^{3}$ questionou-se quanto à sua primeira escolarização, a seguir, quanto a momentos marcantes da ação docente e, posteriormente, como sua prática foi consolidada.

15 É importante lembrar que práticas são criadoras de "usos ou de representações" que não são de forma alguma redutíveis à vontade dos produtores de discursos e de normas. (CHARTIER, 2002). Nesse sentido, a cultura local revelou uma forma de organização coletiva que "incluiu" o rural como lugar de pertencimento frente às representações postas pelo "mundo social" urbano. Para esses professores, pertencer ao campo representou "[...] identidade construída [...] mostrada e reconhecida [...]" pela força da oralidade, dos discursos que se denunciaram à margem e foram submetidos a uma organização baseada na cidade. (CHARTIER, 2002, p. 11).

16 Cabe esclarecer que a escolha pela metodologia da história oral ajuda a aprofundar a compreensão sobre o contexto em que está inserida a trajetória da professora Gersy e da professora Élia. Com Thompson (1992) aprende-se que a abordagem da História, a partir de evidências orais, permite ressaltar elementos que, de outro modo, por outras estratégias investigativas, seriam inacessíveis.

No âmbito das representações e da produção de sentido, as entrevistas são tratadas como encontros sociais, nos quais conhecimentos e significados são ativamente construídos no próprio processo da entrevista ; entrevistador e entrevistado são, naquele momento, coprodutores de conhecimento. Participação, neste nível de interação, envolve ambos em um trabalho de produção de sentido, no qual o processo é tão importante para a pesquisa como o é o sentido produzido.

18 A partir da análise documental buscou-se identificar o modo como em diferentes lugares e momentos uma determinada realidade social é construída no entrecruzamento de aspectos que emergiram na construção dos documentos orais e organização das informações de diferentes naturezas como documentos orais, escritos e iconográficos.

19 Para Bastos, Lemos e Busnello (2007), a análise de imagens, na perspectiva da História Cultural, é uma proposta ou protocolo de leitura, sugerindo ao leitor a compreensão do texto e do seu significado. Nesse sentido, as imagens são apresentadas, como memória, no caso da professora Gersy e Élia ou, no caso da produção de uma história específica com um propósito, uma intenção que necessita ser lida no seu contexto.

20 A iconografia na história (Burke, 2004 ; Paiva, 2002 ; Fabris, 1998), e, especialmente, na História da Educação (Bencostta, 2003 ; Souza, 2001, Franco e Alves, 2004 ; Quadros, 2005), tem sido analisada como um registro histórico que merece um tratamento 
interno e externo pelos pesquisadores. Para Burke (2004:17), a imagem constitui uma forma importante de evidência histórica e nos permite 'imaginar' o passado de forma mais vívida. $\mathrm{O}$ pesquisador deve ler a imagem em seus diversos elementos e planos, identificando mensagens e motivações, o que implica uma leitura de temas e significados, que trazem as formas expostas na imagem, e o contexto de produção e recepção. (BASTOS, LEMOS, BUSNELLO, 2007, p.42).

$21 \mathrm{Na}$ medida em que os sujeitos se recordaram suas memórias foram produzindo encontros, compartilhando experiências, práticas, esquecimentos e o mais importante as conquistas e aprendizagens. Essas "imagens-memórias", exteriorizadas em narrativas, formaram cenários de marcas de identidades, construindo a invencibilidade de uma demarcação necessária da própria prática no contexto que emergiram.

Bastos, Lemos e Busnello (2007), apoiados em Dubois, argumentam que não existe um método para analisar imagens. Entendem que as imagens são representações culturais e que possuem uma função simbólica. A imagem é um objeto cultural sobre o qual existe um saber que deve ser apropriado pelo investigador.

Pimentel (2001) argumenta que o documento representa uma interpretação de fatos elaborados por seu autor, e, portanto, não devem ser encarados como uma descrição objetiva e neutra desses fatos. A análise é sempre um processo interpretativo e construído historicamente. Assim, ao evocar memórias é possível perceber, na trama de relações de poder, como os sujeitos se situam ao longo de suas carreiras profissionais, revelando interesses e motivações não absolutamente possíveis de tornarem-se públicos anteriormente.

\section{O contexto cívico nacionalista brasileiro}

Para Saviani (2005), no século XX, no Brasil, podem ser distinguidos três momentos da política educacional. No primeiro (1890 a 1931) - o federalismo foi predominante - quem viabilizava a oferta escolar primária eram os estados. Já no segundo momento (1931 a 1961), a União busca regulamentar o ensino. O terceiro (1961 a 2001) caracterizou-se por uma concepção pedagógica voltada para a produtividade e o nacionalismo. Entre a implantação da República e o Golpe do Estado Novo observam-se muitas reformas, que dizem, entre outros assuntos, sobre organização curricular e equiparação entre escolas privadas e públicas.

$\mathrm{O}$ século XX também assistiu a inúmeras transformações, no que se refere ao espaço rural, o Brasil passou de uma sociedade eminentemente agrária a uma sociedade industrial, e a cidade assumiu a posição de guia, de modelo dos paradigmas culturais e sociais. Almeida (2007) argumenta que as mudanças econômicas e sociais promoveram transfigurações identitárias e, portanto, afirmou-se uma tendência de construção de identidades urbanas, associando a cidade o status de progresso.

No contexto educacional brasileiro, com o advento da República, abriu-se um processo de mudanças estruturais que se pautavam na consolidação do trabalho assalariado e melhoramentos urbanos aliados ao início da industrialização. Os novos olhares para a educação indicavam o caráter público, universal e laico. O paradigma republicano promoveu uma reestruturação do Estado, que buscava na escolarização uma possibilidade alternativa para acompanhar as transformações que vivia o país nessa época. No intuito de contribuir para nacionalização do país através da escola, surgiram 
iniciativas de diferentes setores da sociedade como o movimento produzido, por exemplo, pelas Cruzadas Nacionais ${ }^{4}$. (GHIRARDELLI JUNIOR, 2009). A partir de 1915, ocorreram campanhas e realizações através da educação, elas pretendiam combater o analfabetismo, difundir a educação primária, defender o patriotismo entre outras ações que primavam pela difusão da educação no Brasil. Essa foi a característica básica do entusiasmo pela educação. A educação seria o maior problema no Brasil, dele decorreriam os outros (sociais, econômicos e políticos). Dessa forma, educar o povo seria primordial para solucionar as mazelas da desigualdade.

Durante a República Velha (1889-1930), época em que se imprimiu na sociedade brasileira o status da modernidade, as escolas rurais mantiveram os aspectos descontínuo e desordenado da época do Império. A educação promovida pelo Estado priorizava o ensino da leitura e da escrita, por exemplo, de meios repetitivos do catecismo cívico-nacional, em que a criança era impregnada de todos os deveres que dela se esperavam, pois como "[...] defender o Estado, pagar impostos, trabalhar e obedecer às leis [...]". (BRITTO, 2007, p. 32). As características alteraram-se apenas a partir da década de 1930 quando o capitalismo atingiu fortemente a zona rural intensificando a necessidade de formação escolar dos camponeses.

O crescimento urbano e industrial que marcou a década de 1930 produziu na população rural aspiração de "[...] ver se seus filhos poderiam, uma vez fora da zona rural, escapar do serviço físico bruto". A questão fundamental da escola continuava sendo "de ensinar a ler, escrever e calcular" .(GHIRARDELLI JUNIOR, 2009, p. 39). A função da instrução salientava-se frente aos novos paradigmas que se projetavam na ótica da formação geral e o desenvolvimento humano do ser humano como um sujeito pátrio, ativo $\mathrm{e}$ atuante.

29 As políticas educacionais, nas primeiras décadas da República, encontravam-se em processo de estruturação. A articulação responsabilizava os Estados pelas transformações representativas que se processaram a partir de Decretos-Lei. o próprio Congresso Constituinte de 1891 determinava que fosse responsabilidade dos Estados e municípios a organização, implementação e manutenção do ensino primário, esvaziando a possibilidade do governo central assumir tais responsabilidades. Nesse sentido, gradativamente, os estados deveriam providenciar reformas de ensino que se adequassem às suas realidades político-educacionais. (BENCOSTA, 2009).

Nesse período, a Instrução Primária contou com iniciativas de diferentes segmentos da sociedade, sob influência do pós $1^{a}$ Guerra Mundial, bem como se firmaram iniciativas que engendraram poder municipal, estadual e federal, em regime de cooperação intensificando a escolarização, dentre estas a ação das Ligas Nacionalistas que contribuíram financeiramente para conter o analfabetismo. A consciência da alfabetização associada ao desenvolvimento produtivo da nação também figurou como característica da influência do movimento conhecido como "otimismo pedagógico".

31 É a partir da década de 1930 que a educação, em âmbito nacional, se torna um direito de todos e obrigação dos poderes públicos. (CURY, 2009). A constituição de um Plano Nacional de Educação, "de Ensino Primário gratuito e obrigatório", vinculando obrigatoriamente um percentual de impostos dos Estados, Municípios e União em favor da educação escolar possibilitou, paulatinamente, a criação de fundos para uma gratuidade ativa da merenda, material didático e assistência médica-odontológica. Essa organização aproximava cada vez mais a escola de uma "educação comum, igual para todos". (GHIRARDELLI JUNIOR, 2009). 

passagem dos jesuítas pelo Estado, bem como a interferência da Igreja presente na escola. Uma das instituições de representação mais expressivas nesse período foi a Igreja Católica. Percebendo que após a Revolução de 1930, as mudanças políticas do Estado poderiam lhe ser muito útil, esforçando-se para romper a separação formal que instituía à Constituição de (1891). A proposta da Igreja aproximava-se dos "escolanovistas", considerando o argumento de que a liberdade de ensino havia produzido práticas perturbadoras, sendo necessária uma fiscalização real e eficiente sobre os professores.

33 A tríade "educação", "instrução" e "cultura" atendia o movimento da década de 1930 , cuja prática de ensino pretendia a preparação física do "poder" e a formação moral do "dever", sob forte influência vocacional, constituído de um programa de educação moral e cívica, [...] que se tornou co-responsável pela transmissão de um conjunto de princípios que corporificavam idéias patrióticas, que eram instrumentalizados nas salas de aula e nas palestras proferidas na escola, cujo principal objetivo era despertar os sentimentos de amor e dever à família, à sociedade e, principalmente, à pátria. É neste ambiente civilizatório que emergem os desfiles e festas patrióticas. (BENCOSTA, 2009, p. 75). público no Brasil, exigindo, inclusive, ingresso na docência por concurso público, no período do Estado Novo (1937-1945) figuram as Leis Orgânicas do Ensino. Destaca-se, a partir de 1942 a "Reforma Capanema" : abrangendo os ensinos industrial e secundário (1942) ; comercial (1943) ; normal, primário e agrícola (1946). Por essas reformas o Ensino Primário foi desdobrado em Ensino Primário Fundamental, de quatro anos, destinado a crianças entre 7 e 12 anos, e Ensino Primários Supletivo, de dois anos, que se destinava aos adultos e aos adolescentes que não haviam tido a oportunidade de frequentar a escola na idade adequada.

o Rio Grande do Sul, essa época apresenta um contexto importante para a educação rural a partir da Campanha de Nacionalização, de abril de 1938. (WERLE, 2007). Durante o Governo Vargas, e sob influencia do Ministro Capanema, a ênfase da educação estava na profissionalização para o trabalho. 0 principal objetivo da política de vinculação educação-trabalho não era obter determinados efeitos sociais e sim formar bons trabalhadores para o capital. "Estes trabalhadores não nascem feitos, têm que ser [...] fabricados. Da escola, esperava-se que contribuísse neste difícil processo de formação fabricar o trabalhador requerido pelo capital". (ARROYO, 1983, p. 17). Pregava-se a escola rural como escola do trabalho e que teria a função de cunho nacionalista de integrar os alunos na obra de construção da unidade nacional para a tranquilidade, segurança e bem-estar do povo. Conforme Gertz (2005), no Rio Grande do Sul, durante o Estado Novo, perseguiam-se três objetivos no campo do ensino básico : ampliação do número de escolas e professores, definição do plano de carreira e elaboração de normas e critérios para as escolas.

Correndo o risco de uma síntese necessária, de forma ampla pode-se afirmar serem essas as políticas públicas no Estado Novo : um nacionalismo exacerbado, em todas as etapas da escolarização, uma centralização de poder e a busca para tornar o sistema de ensino homogêneo, nem que para isso fosse preciso afastar aqueles que manifestassem alguma contrariedade. 
37 Após este período de centralização, na década de 1950, surgem ações identificadas com uma tendência autonomista. No início dos anos 60, desenvolvem-se procedimentos administrativos tendentes à descentralização do ensino primário. Nesse sentido surgem inúmeras "frentes de irradiação do analfabetismo", incluindo a "Campanha Nacional de Educação Rural". (WERLE, 2009).Em 1947, termina o regime do Estado Novo, mas as instituições criadas permanecem. Apenas alguns de seus institutos se dissolveram, como a Juventude Brasileira e a instrução pré-militar. Outras tantas criações do período subsistem : as festas e desfiles, a obrigatoriedade da educação física, comercial, industrial. Começam, entretanto, novos processos. O projeto da Lei de Diretrizes e Bases da Educação Nacional é longamente debatido e tramita no Congresso Nacional de 1948 a 1961. (WERLE, 2009, p. 45).

Quanto à estrutura federativa educacional em 1953, a educação e a saúde separaram-se a partir da criação do Ministério da Educação e Cultura (Decreto-lei $\left.\mathrm{n}^{2} .1920,1953\right)$, alterando novamente esta designação, em 1985, quando passou a Ministério da Educação (Decreto-lei $\left.\mathrm{n}^{\circ} .91 .114,1985\right)$ produzindo reorganizações em diferentes partes do país, o que se refletiu também nas práticas de inspeção, supervisão e orientação de ensino (WERLE, 2009).

Na década de 1960, as mudanças profundas, no contexto político, repercutiram diretamente no sistema educacional. Com a renúncia de Jânio Quadros e a deposição de João Goulart, o país esteve exposto a uma série de mobilizações que demonstraram a existência de um nível de consciência por parte de sua população. No setor econômico, a partir de 1964, o país conheceu um "modelo capitalista periférico, associado e subalterno", cujo efeito foi sentido nas transformações sociais que modificaram as práticas educacionais a partir da DIMEP - Divisão de Municipalização do Ensino Primário. (VECCHIA ; HERÉDIA ; RAMOS, 2008, p. 28).

40 A Lei 4.024/61 teve um papel fundamental para o desenvolvimento e promoção do ensino primário, além disso, a escola passou a ser “[...] controlada e avaliada de forma inédita [...] para que [...] não fossem um espaço de educação popular, mas uma forma de gerar produtividade e eficiência do próprio processo educacional". Nesse contexto, surge o Serviço de Expansão Descentralizada do Ensino Primário, criado no Rio Grande do Sul, em 1960 e reestruturado em 31 de dezembro de 1965, mediante o Decreto 17.750. Na instância municipal, acordos e subvenções se firmaram numa articulação entre Estado e Municípios formando a Divisão de Municipalização do Ensino Primário. "Essa divisão teve por finalidade promover a celebração de acordos e convênios [...] objetivando a expansão da rede municipal e a descentralização do ensino primário". (VECCHIA ; HERÉDIA ; RAMOS, 2008, p. 28).

41 No final da década de 1960, princípios e leis complementares expressaram aspectos presentes na legislação anterior, porém a Constituição Federal de 1967 e as leis complementares de 1969 estabeleceram a obrigatoriedade do ensino às crianças de sete a catorze anos, bem como a proposta do tecnicismo orientou a produtividade e eficiência do ensino identificados nos princípios da Lei 5692/71. A LDB de 1971 permaneceu treze anos no Congresso, portanto, negando-se a possibilidade da discussão e construção pelo poder legislativo, sendo aprovada sem nenhum veto presidencial. (GHIRARDELLI JUNIOR, 2009).

42 Conforme Calazans e Silva (1993), a inserção do ensino (regular, formal e oficial) em áreas rurais iniciou no final do Segundo Império a partir das classes de mestre-único e ampliou-se na primeira metade do século XX. O seu desenvolvimento reflete, de certo 
modo, as necessidades decorrentes da evolução das estruturas socioagrárias do país. É nesse contexto que a escola rural se instaurou tardia e descontinuamente.

As classes multisseriadas ainda se conservam como única alternativa para a escolarização das comunidades “[...] de difícil acesso e não pode ser entendido como um momento precário, uma medida paliativa, provisória. Um número significativo de alunos, professores e pais dependem e fazem seu cotidiano a partir destas escolas". (FERRI, 1994, p. 17). Embora as classes multisseriadas existam em espaços urbanos, o "interior" parece ter se configurado como lugar privilegiado dessa prática. 0 argumento da adversidade às condições físicas espaciais e o reduzido número de alunos das comunidades rurais colaboram para a continuidade desse tipo de escola. A função da escola rural confunde-se com o conceito que a acompanha, pois as escolas rurais, de mestre único, multisseriadas, fazem parte da história da educação brasileira. Enquanto que as escolas rurais criadas para preparar o homem produtivo que, além dos conhecimentos básicos dominasse as técnicas de plantio e fosse garantia de melhor produção, foi sistematizada pelo Decreto-lei 9613, de 20 de agosto de 1946, como Lei Orgânica do Ensino Agrícola. (MIGUEL, 2007, p. 83).

A educação rural foi vista como um instrumento capaz de formar, de modelar um cidadão adaptado ao seu meio de origem, mas lapidado pelo conhecimento científico endossado pelo meio urbano. Ou seja, a cidade é quem apresentava as diretrizes para formar o homem do campo, partindo daí, os ensinamentos capazes de orientá-lo, civilizá-lo a bem viver nas suas atividades, com conhecimentos de saúde, saneamento, alimentação adequada, administração do tempo, técnicas agrícolas modernas amparadas na ciência, etc. A escolarização deveria preparar e instrumentalizar o homem rural para enfrentar as mudanças sociais e econômicas. Dessa forma, o sujeito do campo poderia participar e compreender as ideias de progresso e modernidade que emergiam no país.

45 A história de Novo Hamburgo está imersa no contexto da colônia alemã de São Leopoldo, principalmente a religião luterana e católica, que no decorrer do século XIX contribuíram para constituição da origem ao Vale dos Sinos (considerando o estabelecimento de colonos ao longo do rio dos Sinos). No ano de 1824, os imigrantes alemães desembarcam na Real Feitoria ${ }^{5}$ do Linho Cânhamo, onde hoje se situa a cidade de São Leopoldo e, alguns meses depois, chegaram aonde hoje se localiza o município de Novo Hamburgo, “[...] posteriormente, expandiram-se para áreas próximas chegando a Lomba Grande". (SchüLtz, 2001, p. 107).

46 Como de costume, a influência religiosa, legado europeu da colonização, sugeria que ao lado de cada igreja deveria haver uma escola ${ }^{6}$. Em Novo Hamburgo, essa situação se reproduziu também no valor dado à educação pelas pessoas que se estabeleceram em Lomba Grande (Dreher, 1984). A tríade (Escola/Igreja e Cemitério) registra também a constituição de um lugar de referência para os moradores da localidade.

47 Com a imigração, floresceu no atual município de Novo Hamburgo uma vida comunitária, característica da convivência européia desses imigrantes. A atividade agrícola e a indústria artesanal caracterizaram a primeira fase de desenvolvimento do vilarejo que se estenderam até 1927.

48 A comunitariedade foi decisiva para a inclusão do motivo religioso na educação. Mencionando Hans Joerg, Lúcio Kreuz chama a atenção para o fato de que além do ensino formalizado do ler, escrever e contar, a catequese, juntamente com o ensino de rezas e cânticos, era prioritária. $O$ aspecto religioso era quesito fundamental para a 
nomeação do professor. São essas características as mesmas que vamos encontrar nas regiões em que se instala o luteranismo no Brasil. A elas deve-se acrescentar que, não raro, os pastores eram também professores e que, muitas vezes, as escolas eram anexos da Casa Pastoral. (DREHER, 2008, p. 23).A vida em comunidade organizava-se em torno de suas escolas, igrejas, considerando o princípio religioso e escolar, entendidos como legado e tradição germânica. Essa prática comunitária revela que no interior de Lomba Grande, no século XIX, existiram as Aulas Domiciliares Públicas e Particulares, bem como a Aula Mista da Comunidade Evangélica e católica.

Em Lomba Grande, a histórias da educação se relaciona à sensibilidade da comunidade e das famílias que cediam compartimentos em suas residências para que fossem ministradas aulas. O professor, em alguns casos também era oriundo da sua comunidade, que apesar da instrução mínima, na ausência de um mestre graduado, desempenhavam a docência superando inclusive as dificuldades de falta de material didático, condicionando-se aos soldos provenientes das famílias.

Em Novo Hamburgo, muitas aulas que se transformaram nos Grupos e Colégios ${ }^{7}$ efetivaram parceria com a instância municipal. Além disso, algumas contavam com subvenções municipais. O Grupo Escolar de Lomba Grande, por exemplo, a municipalidade arcava com o pagamento do aluguel, bem como havia reserva de recursos que se destinava a aquisição de materiais. Na instância regida pelo município na década de 1950, as aulas passaram a se chamar Escolas Isoladas, pioneiras das EMEFs, da década de 1990.

51 Em 1960, é criada a SEDEP (Serviço de Expansão Descentralizada do Ensino Primário), nessa época, muitas escolas públicas são construídas, contratos e acordos de entes (municipal e estadual) possibilitaram a ampliação do atendimento educacional, principalmente, a partir das chamadas brizoletas. Nesse sentido, foram construídas 21 escolas em Novo Hamburgo, sendo que destas, cinco se localizavam em Lomba Grande. Em 1966, esse serviço é substituído pela Divisão de Municipalização do Ensino Primário (DIMEP), permanecendo com a mesma intenção de articulação entre governo municipal e estadual, conforme Lei Municipal no 15/66.

52 Almeida (2001) argumenta que nesse contexto de transformações da década de 1960 houve a expulsão de mão-de-obra do campo, ocasionando uma aceleração do fluxo migratório campo-cidade, como desagregação das pequenas propriedades em detrimento à industrialização e urbanização.

53 O intenso movimento migratório que produziu o processo de urbanização no Brasil na década de 1970 e a grande oferta de mão-de-obra, principalmente, para as indústrias, no caso de Novo Hamburgo, a coureiro-calçadista, redimensionaram o espaço de aprendizagem no espaço rural. Ao mesmo tempo em que houve a preocupação, num primeiro momento, de conter esse fluxo populacional, a partir do "desenho" de uma escola que atendesse às necessidades imediatas da população do campo, houve também o crescimento do número de estabelecimentos de ensino cuja proposta atendia à preparação mínima para o trabalho, fosse ele no campo ou na cidade.

54 A partir dos estudos de Schemes (2006), Martins (2011) e Selbach (1999) constata-se que Novo Hamburgo viveu até a década de 1970 um processo de urbanização e após um período de industrialização. Nesse período, o município conheceu o "milagre brasileiro". Esse aspecto reforçou a representação e imaginário de que Novo Hamburgo ajudaria a construir um país moderno por meio da venda, além-fronteiras, do calçado fabricado. O "milagre econômico" evidenciou-se em diferentes setores da estrutura 
social local, principalmente na educação do município que recebeu os dividendos dessa riqueza. (MARTINS, 2011).

\section{O desfile cívico : a festa da pátria nas memórias de duas professoras}

Primária para divulgar os preceitos de civilidade e inspirar o nacionalismo cívico. Pretendia-se levar o Brasil a modernidade moldando os sujeitos e educando-os condutas, boas maneiras, regras e comportamento ordeiro, cosmopolita para que tivessem a conduta esperada pela "boa sociedade".

61 Esperava-se do professor primário, no contexto nacionalista, que desenvolvesse a educação das crianças pelo seu próprio exemplo moral de civilidade, pois o professor deveria ser o primeiro a ter em seu corpo as marcas de civilidade impressas. (CUNHA, 
2009). 0 professor, contido e recatado seria os representantes legítimos na constituição dos valores morais “[...] construtores da Nação [...] propagava [...] qualidades morais (boas maneiras, bons antecedentes, bons hábitos [...]) o que comporiam a figura do(a) professor(a) e dariam um sentido nobre à profissão docente". (CUNHA, 2009, p. 239).

As professoras Maria Gersy e Élia Thiesen, professoras primárias, compõem o cenário docente e o contexto da filosofia da escola nova, aspectos que pautaram práticas pedagógicas que associaram o magistério ao sentimento de "servir" o público, a nação e construir uma "legião de soldados" para pátria. (FISCHER, 2005).

A trajetória docente da professora Maria Gersy Höher Thiesen desenvolveu-se em diferentes localidades do bairro rural Lomba Grande, a saber : nas Aulas Reunidas do Grupo Escolar de Lomba Grande e no Jardim da Infância Getúlio Vargas ; São Jacó, na Escola Municipal Humberto de Campos ; localidade de Santa Maria, na Escola Municipal Expedicionário João Moreira e no Passo dos Corvos, na Escola Municipal Castro Alves, no período de 1940 a 1969.

64 A professora Élia Maria Thiesen, cunhada da professora Gersy, foi docente na Escola Humberto de Campos na localidade de São Jacó, onde desenvolveu toda a sua vida de professora, no período de 1958 a 1983.Analisando as narrativas de memórias das práticas das professoras investigadas foi possível reconhecer os traços culturais distintos, que são regulados pela cultura, no sentido que os conceitos e as categorias de uma cultura particular determinam os modos pelos quais seus membros perceberam e interpretaram o que lhe aconteceu em sua época (BURKE, 1992).

Maria Gersy nasceu em 18 de março de 1924, na localidade de "Rosenthal", atual localidade de Santa Maria, filha do professor José Afonso Höher e da escrivã Erna Olinda Höher. "Gersy", como carinhosamente era chamada pelo pai, educador pioneiro no Vale dos Sinos ${ }^{8}$, que no final do século XIX, era responsável pelas aulas particulares e em seguida pela instituição das aulas públicas na localidade. As memórias das aulas públicas e que foram depois reunidas e constituíram o Grupo Escolar de Lomba Grande foram avivadas no momento em que Gersy também alcançou algumas fotografias. A fotografia número 1 registra o Grupo Escolar de Lomba Grande na década de 1940, a frente dos alunos a professora Julieta Höher. 
Fotografia 1 : Desfile cívico, Lomba Grande, aproximadamente em 1940

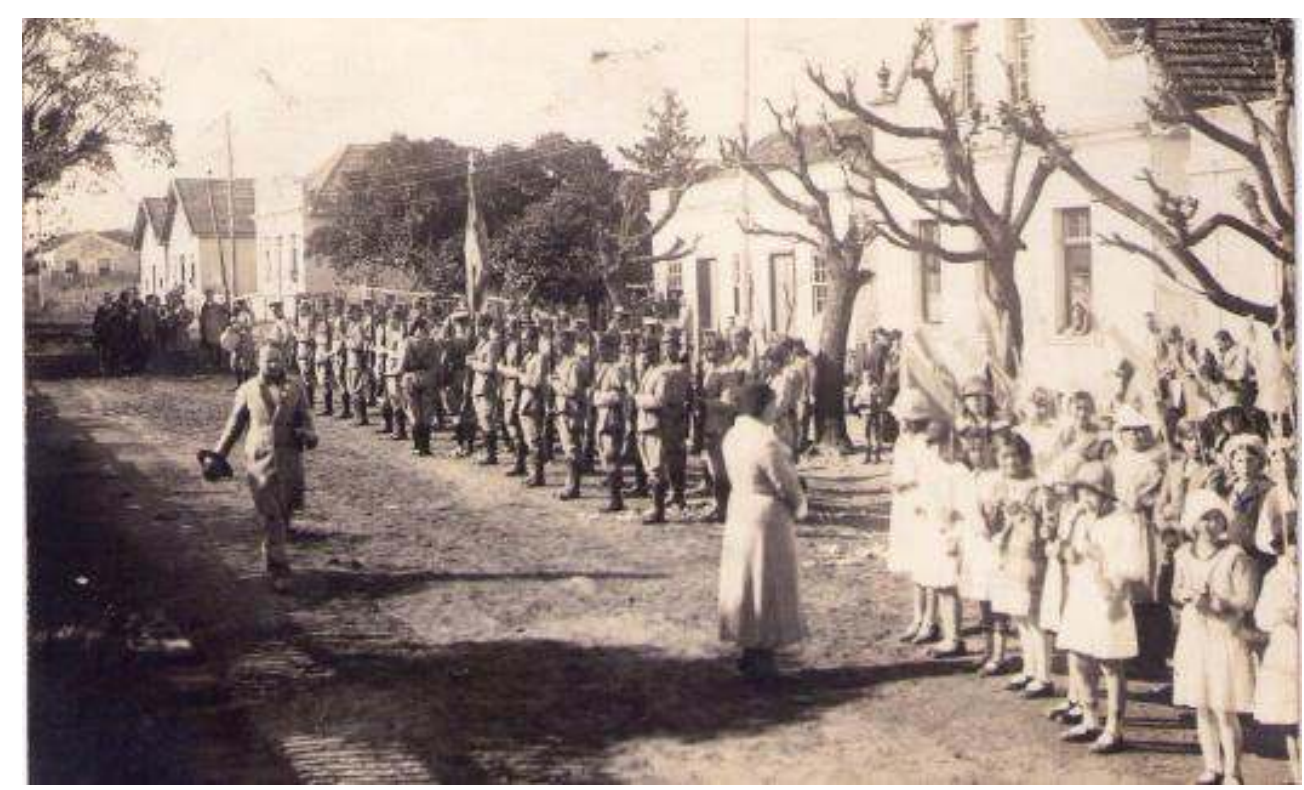

Fonte : Acervo particular da professora Maria Gersy Höher Thiesen, 2010

66 A fotografia destaca a Rua João Aloysio Allgayer, região central do bairro. Ainda observa-se o industriário Paulo Fack Felles e ao fundo o Tiro de Guerra de Lomba Grande. E Gersy ainda rememora que nesse dia os pais costumavam reservar o melhor traje, a indumentária de domingo. As meninas costumavam usar meia-calça branca, saia plissada e/ou vestido. O chapéu com mais copa e menos aba, característico dos anos 1930, estilo "toucados". E ainda era comum todos acenarem a bandeira do Brasil com muito orgulho e exatidão quando estavam diante das autoridades. "[...] Alguns alunos recitavam poemas [...] e tinha o canto orfeônico do coral do grupo [...]". (Gersy, 2010). Havia uma comoção geral da platéia que espera ansiosa pelas apresentações e principalmente a demonstração da grandiosidade e do poder que a nação representava com as armas e a marcha dos soldados.

O sentimento de amor à pátria era constituído por meio da difusão da beleza e da grandeza da terra brasileira. O Brasil possuía rios enormes e grandiosas florestas, clima ameno, riquezas minerais sem fim e uma história sem feitos deprimentes ou vergonhosos. Olavo Bilac, Afrânio Peixoto, dentre outros, prosseguiram nessa tarefa e, por essa trilha, foi sendo construída uma galeria de heróis nacionais que passaram a ser cultuados em festas cívicas de rituais cuidadosamente preparados. (BITTENCOURT, 2005).

o feriado era um momento muito esperado pelos alunos e também pelas moças solteiras. No espaço rural de Lomba Grande, as meninas eram motivadas pelo sentimento nacionalista e envolviam-se em obras de caridade. Na fotografia 2, Gersy, em destaque, e suas amigas no gramado da Igreja São José. A roupa branca indicava a pureza, a higiene e foi, naquele contexto, a cor escolhida para todas as moças que trabalharam na quermesse de arrecadação de fundos para caridade. As moças costumavam se organizar e vender bolos, fitinhas e organizar a reunião dançante. $\mathrm{Na}$ ocasião desta fotografia, aproximadamente em 1942, Gersy recorda ter colocado uma "fitinha" na lapela do seu futuro marido, José Antônio Thiesen. 
Fotografia 2 - moças da comunidade católica São José, Lomba Grande, aproximadamente em 1942

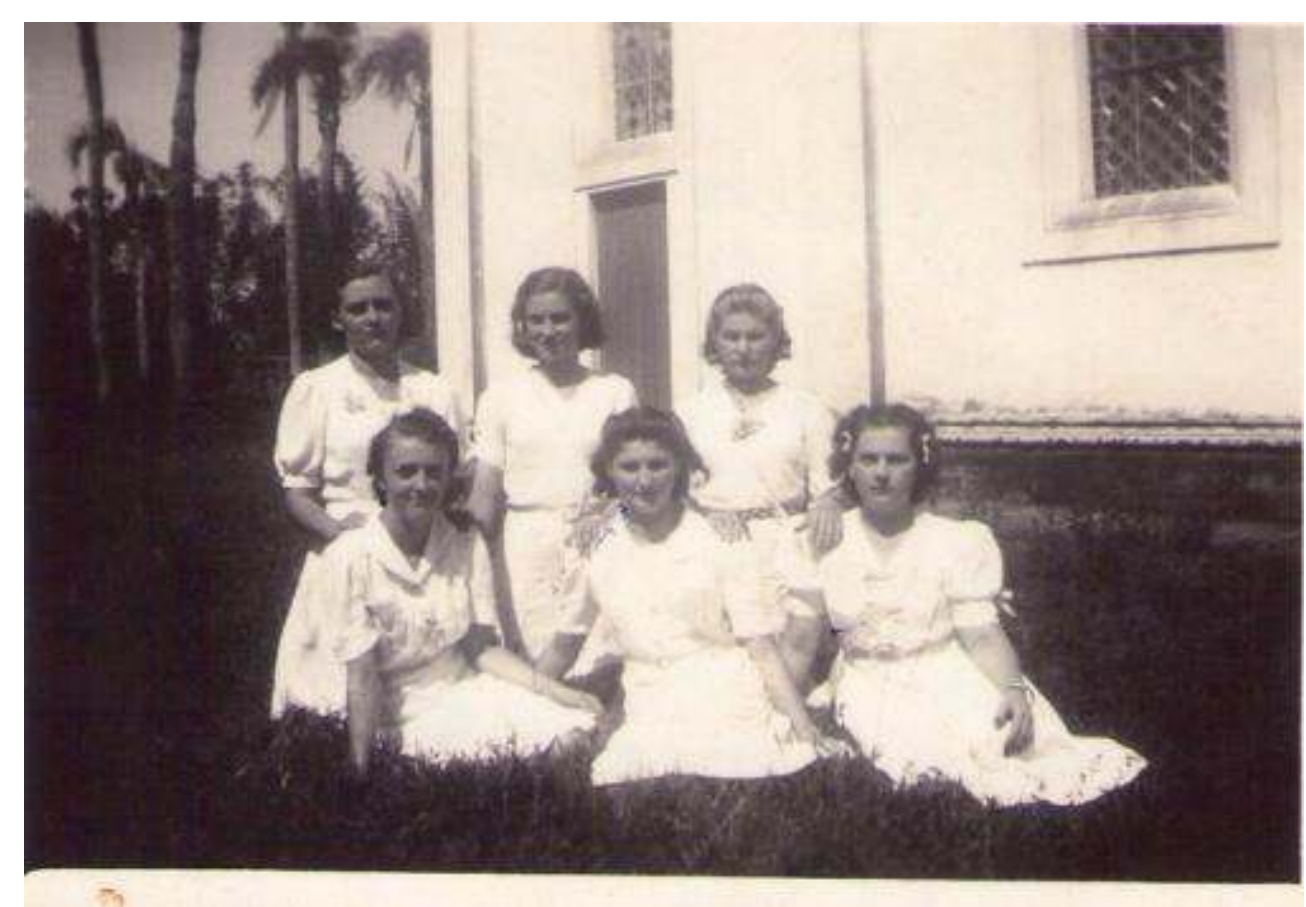

Fonte : acervo pessoal da professora Maria Gersy Höher Thiesen, 2010

Como se observa na fotografia 2, além do desfile cívico, costumava acontecer missa campal e/ou na Igreja, apresentação de bailados e as tendas com brincadeiras e produtos típicos do lugar. Algumas famílias que se deslocavam de localidades muito distantes faziam o piquenique e ao término da missa, as comadres e compadres conversavam e a atualização sobre os assuntos da sede (cidade) era a pauta de discussão da comunidade que se reunião em torno da festa da independência. As fotografias 3 e 4 enfatizam esses momentos, ressaltando a missa campal. 
Fotografia 3 - missa campal, comunidade católica São José, Lomba Grande, aproximadamente 1938

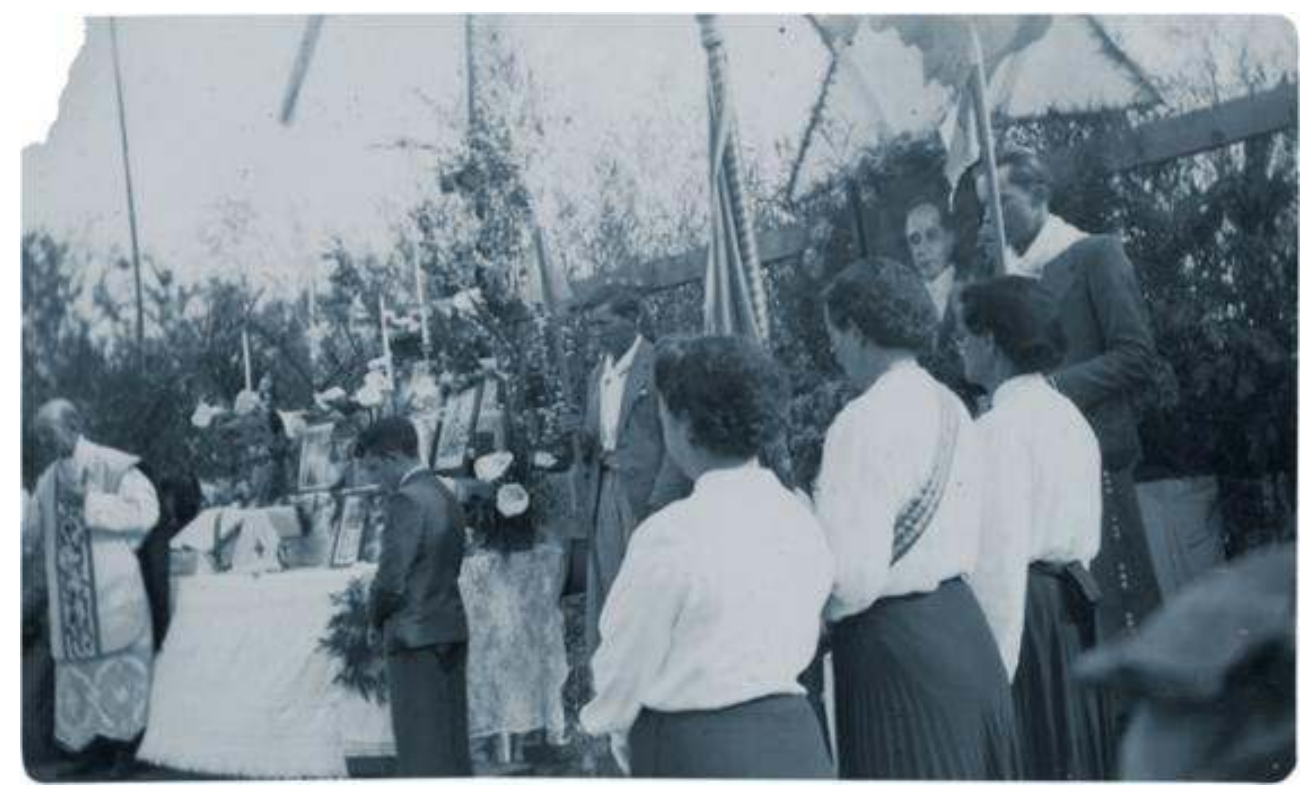

Fonte : acervo virtual pessoal de Moisés Braun, 2011.

70 A identidade nacional e a difusão de um sentimento nacional patriótico nas escolas republicanas caracterizam, dessa forma, o que se chama de nacionalismo de direita. Trata-se de um nacionalismo voltado para atender aos interesses de determinados setores das elites nacionais, voltados para projetos de manutenção de seu poder e privilégio, como se observa nas fotografias 3 e 4, a exaltação do culto ao presidente Getúlio Vargas, ocupando lugar de destaque no altar ao lados dos santos. Predominava a ideia de união, que omitia qualquer tipo de manifestação de descontentamento interno das camadas sociais dominadas, evitando tratar das diferenças regionais, sociais ou culturais. (BITTENCOURT, 2005, 102). 


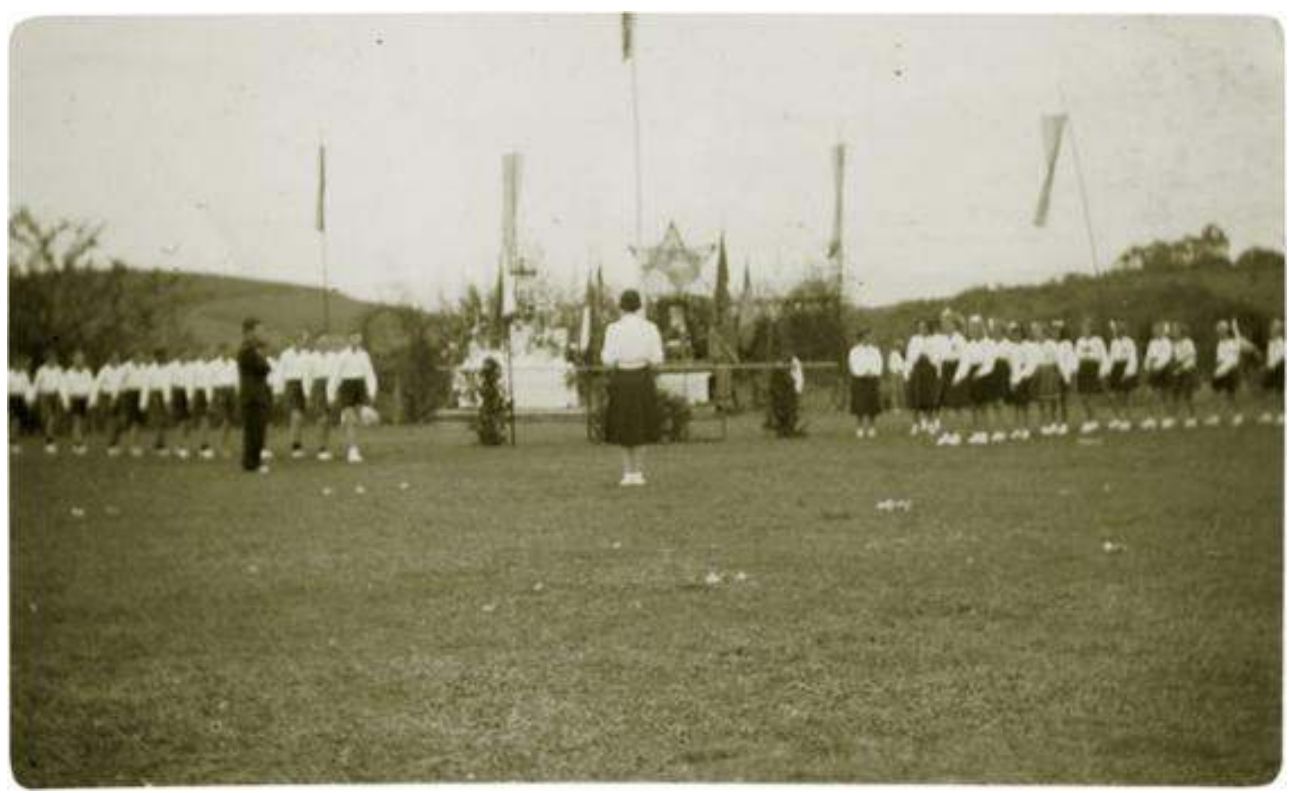

Fonte : acervo virtual pessoal de Moisés Braun, 2011

71 No contexto das práticas pedagógicas nas aulas isoladas, então atuando como professora, Gersy lembrou o aspecto cívico, uma situação que lhe deixou muito orgulhosa :Eu tinha o meu Jardim da Infância, e eles cantavam o Hino Nacional todinho de fio a pavio. Quando o Grupo fazia uma festa o Jardim fazia parte. [...], depois a mamãe me contou :Gersy, tu nem sabe como eu fiquei faceira, como eu fiquei orgulhosa. Porque [...] quando foi passado da primeira pra segunda estrofe [...], o grupo embatucou e quase pararam o Hino Nacional junto com o professor de música. E o meu jardim, [continuou] cantando o Hino Nacional. Isso, até hoje, eu sinto uma alegria quando eu [...] lembro-me da minha mãe me contando, da satisfação dela - e o povo notou!

Gersy destacou que seus alunos do Jardim da Infância, saiam-se muito bem nas aulas de Canto Orfeônico. Ela se emociona ao contar essa prática, registra que a comunidade presente, na festa cívica alusiva aos festejos da pátria percebeu que os alunos do canto coral do Grupo Escolar de Lomba Grande, "embatucaram", se perderam na letra do Hino Nacional e foram seus alunos que "seguraram" a canção.

Gersy ainda recorda os momentos que levava os "pequenos" alunos, do Jardim da Infância "Getúlio Vargas" até o pátio do Grupo Escolar de Lomba Grande, no gramado ao lado da Igreja Católica São José. Ela sentava os alunos em círculo, permitia que eles brincassem com a terra e delegava tarefas para os alunos. Esse exercício constituía-se na criação de uma rotina, com o ensinamento sobre o "cuidar" em todos os sentidos, o que revelou também a sua preocupação docente, na preservação da natureza, no aprendizado da convivência em grupo e do cuidado com o próximo. Nessa prática, incluía-se buscar água, preparar a terra para o canteiro, separar as mudas de cravinas, o plantio e a conservação desse espaço por todos os alunos.

Werle e Metzler (2009) argumentam que no $8^{\circ}$ Congresso Brasileiro de Educação, discutia-se sobre a construção de uma prática de orientação rural para as escolas e indicavam o cultivo de quintais, roças e o desenvolvimento do artesanato. Sobre isso, recorda a professora Gersy :E aí disse : essas crianças vão ter que trabalhar um pouquinho, vão ter que ter amor à vida. [...] fiz um canteirinho redondinho, onde, [bate na mesa como se 
fosse andadura de cavalo]. Fiz um canteirinho redondo daquelas "cravilinas" cheirosas, onde eles tinham que cuidar e isso fazia parte daquele jardinzinho, cuidar da natureza.Esse sentimento pátrio ainda se expressa na sua carta de despedida, escrita em 1969, quando se aposentou, como se observa abaixo.Estou aposentada [...] Interessante é que não me sinto muito satisfeita, pois já sinto agora saudades, - dos rostinhos mimosos dos alunos, dos colegas, que estimo tanto, - da tão devotada e meiga $D^{a}$. Amélia, a nossa querida servente; enfim de tudo isso que foi minha vida de professora. Nela houve lutas, - desenganos, mas muitas horas felizes. [...] Peço a Deus, que dê, a cada professora [...] tudo aquilo que sempre quis dar aos meus filhos de 4 horas diárias, pois por cada criança senti o afeto de mãe, procurei dar o que de melhor tinha a dar : amor. Sei que errei muitas vezes, mas sou humana e não divina [...] jamais fui professora de fim de mês, consegui fazer daquelas que me foram confiadas, criaturas úteis a Deus, à Pátria, à Sociedade, eduquei-as, enfim, para serem felizes. [...] Adeus, Gersy (Documento 2).

Werle e Metzler (2009) argumentam que durante muitos anos o "entusiasmo cívico" esteve incorporado às atribuições daqueles que desejassem exercer o magistério. 0 sentido filosófico da profissão expresso nas memórias dos sujeitos entrevistados revela que a docência foi por eles interpretada, acima de tudo como vocação, como registrou a professora Gersy em sua despedida, ser professor significava "educar as crianças como filhos" da "Pátria amada Brasil".

Élia inicia a entrevista falando sobre as memórias da sua escola, com muito carinho recorda as paredes, o espaço, as professoras, uma a uma elas reacendem pela lembrança. Ela nasceu no dia dezenove de março de 1938, em São Leopoldo, na localidade de Feitoria Velha, nas imediações que limitavam Feitoria à Lomba Grande. "Era do lado de cá daquele arroio, era a divisa de Lomba Grande e São Leopoldo, só que o pai tinha terra nos dois lados".

Filha de Irma Paulina Daudt e Germano Reinaldo Schilindwein recorda que viviam na zona rural e todo sustento da família "[...] dependia da roça, o dinheiro, tudo vinha da roça, da horta ; tinha gado também. [...]". Com família numerosa e muita dificuldade trás a marca da "vocação" quando lembra "[...] com seis anos eu batia o pé dizendo que eu queria ser professora, falava só em alemão - quero ser professora. Alguém perguntava e eu já diziaquero ser professora [risos], mas não sabia como. [...]". Na escola Mathilde de Albuquerque, concluiu o $5^{\circ}$ ano. Quando ela tinha treze anos, uma amiga resolveu trabalhar no Colégio São José, em São Leopoldo, o forte vínculo de amizade favoreceu para que ela convencesse o pai a autorizá-la a trabalhar na copa da instituição para ficar próxima da amiga.

o desejo de ser professora permaneceu com Élia e foi percorrido, mesmo em casa, enquanto auxiliava o pai na roça e na dedicação à catequese. Com dezoito anos, em 1956, ela se casou com Victor Thiesen, filho de Jacó Thiesen. A história da trajetória docente dessa professora se entrecruza a sua história de vida. Toda a experiência docente de Élia aconteceu na Escola Humberto de Campos - escola construída pelo sogro para a professora Maria Gersy, cunhada da professora Élia -, na localidade de São Jacó, que recebeu essa denominação em função da Igreja que fora construída, pelos "Jacobs" ; as terras da localidade pertenciam, inicialmente, a Jacó Thiesen e Jacó Plentz. Bittencourt (2009) argumenta que nas primeiras décadas do século XX os programas de ensino das escolas primárias e secundárias incorporaram ao currículo atividades que enalteciam e homenageavam os "heróis nacionais". Além dos heróis, a escola da república, no Brasil, deveria desenvolver um sentimento nacional. Um ritual cívico e 
pátrio foi instituído no cotidiano das escolas e que envolvia a prática de hastear a bandeira nacional, execução de hinos pátrios, dentre outras atividades.

Élia rememora que seu planejamento sempre "demandou muito tempo", pois "planejar pra quatro séries assim não tem como, precisa 4 horas de trabalho e mais 4 horas de planejamento diário". Contudo, lembra-se das exigências que o tecnicismo proposto pelas políticas educacionais no final dos anos 1970 exigia um grande trabalho burocrático.Como Élia acumulava a função de regente, ou seja, diretora da Escola Humberto de Campos, o registro de todas as horas cívicas, dos poemas que eram recitados e os heróis que, nas datas comemorativas eram homenageados, deveriam constar em um livro de atas específico que era inspecionado pela supervisora das escolas rurais do bairro, na década de 1970, sob a responsabilidade da professora Emi Sauer.

81 Na escola, o ritual da Semana da Pátria envolvia além dos preparativos para o desfile, as apresentações que os alunos deveriam preparar para apresentar nos momentos cívicos que se realizavam todos os dias. Havia recital de poemas e apresentação de cartazes com honras e homenagens aos heróis nacionais. "Ainda era preciso trabalhar o que eles mandavam, os conteúdos, tudo numa planilha [...]". A secretaria municipal de educação organizava orientações e antecipadamente sugeria atividades, bem como enfatizava o tema nacional e/ou regional que seria o foco de trabalho para desenvolver o civismo anualmente. A professora Élia relembrou o compromisso cívico com a Nação, destacando o desfile de Sete de Setembro, conforme se observa na fotografia 5.

Fotografia 5- Tradicional desfile cívico na rua João A. Algayer, Lomba Grande,década de 1976

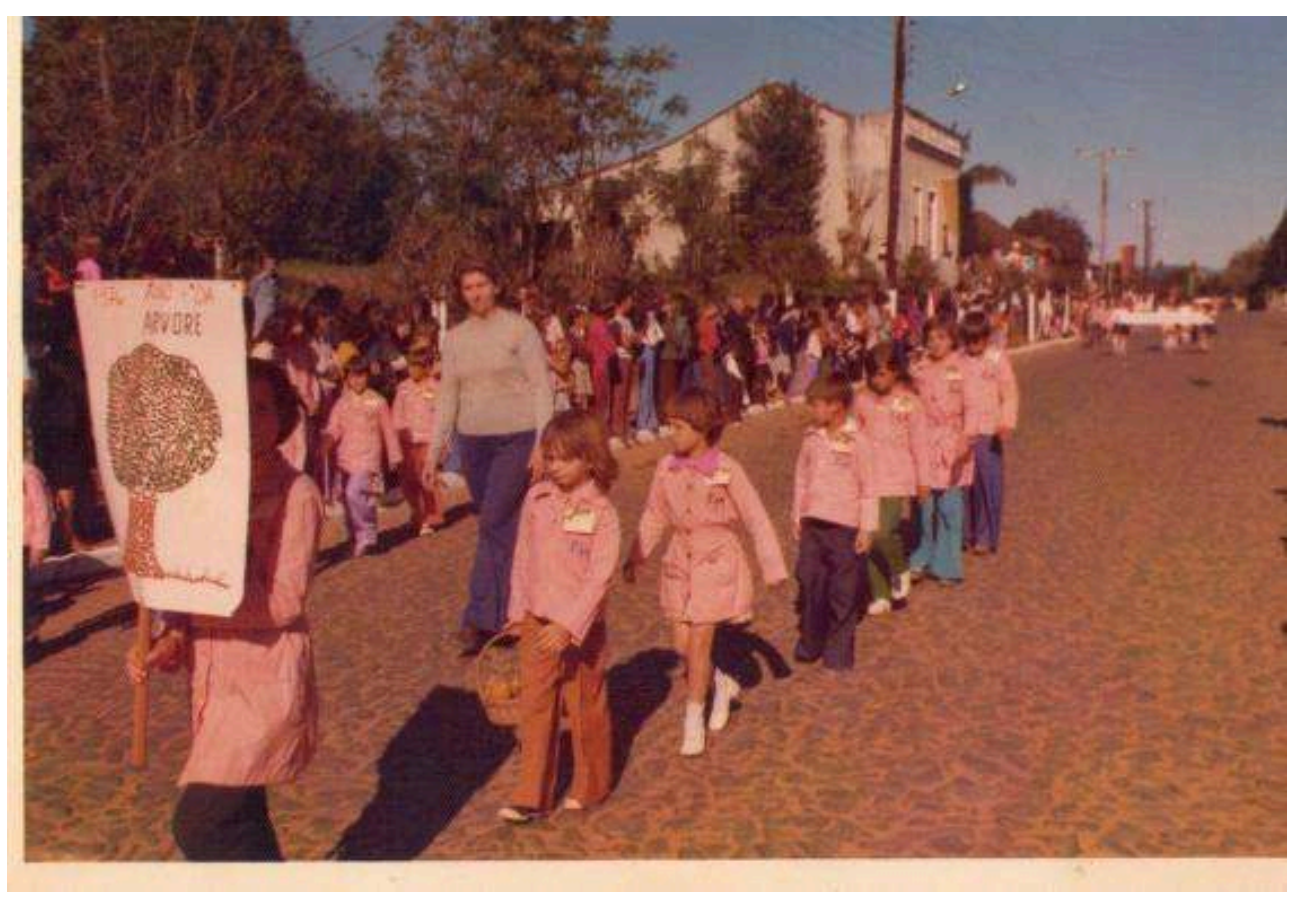

Fonte : Acervo pessoal da professora Élia Thiesen, 2010.

82 O aspecto cívico do desfile de Sete de Setembro foi lembrado como um momento que todas as escolas do interior se encontravam na região central do bairro Lomba Grande. Tradicionalmente, o desfile ainda acontece antecipadamente, sendo único bairro do município que possui um dia "especial" para esse festejo. Observa-se na fotografia 5 que 
os elementos da natureza, bem como os produtos agrícolas figuravam em destaque no desfile, da década de 1970.

Para Bittencourt (2009), o professor tem como responsabilidade prática docente, através da instituição escolar legitimar a tradição nacional, a cultura, as crenças, a arte do território. É através da sua prática pedagógica que o professor contribui para transmissão de uma memória nacional. Em Lomba Grande, com as memórias das professoras Gersy e Élia percebem-se os "quadros de memórias coletivas" que configuram um "Tempo Social" compartilhado em fragmentos dessas duas trajetórias, no sentido que Halbwachs (2006, p.36) trata os testemunhos e significados que os indivíduos atribuem aos episódios coletivos. Portanto, “[...] as impressões que tivemos e que nos marcam estão circunscritas no âmbito das relações que mantivemos, dos grupos que integramos".

84 A festa da pátria é entendida como uma festa tradicional, construída e inventada, ou seja, uma festa de "tradição nacional". A escola, principalmente a partir da década de 1920, parece ter incorporado às suas práticas pedagógicas o conteúdo patriótico, “de teor nacionalista". Conforme Bittencourt (2009), os desfiles estudantis envolviam além da apresentação pública, a demonstração de ginastas. A escola se encarregava de reiterar, por meio de diversas atividades pedagógicas, os valores e princípios da "unidade nacional" contidos nos projetos educacionais.

O civismo se concretizou no ideário escolar não somente através de desfiles, mas também, por meio de culto a heróis e a saudação à pátria por meio dos hinos. A partir do culto ao civismo, desenvolviam-se em cada sujeito instrumentos eficazes para atingir a cabeça e o coração de cada um a serviço da legitimação de regimes políticos. As manifestações simbólicas, como os hinos e as bandeiras foram símbolos fundamentais para a legitimação da forma de governo republicano. (CARVALHO, 2011).

Uma reflexão pertinente quanto ao sentimento de pertença, do culto às memórias que foram evocadas nas entrevistas realizadas com Gersy e Élia é o aspecto da legitimação desta tradição e manutenção desta prática na escola, o que se associa aquilo que Hobsbawm e Ranger (1984) identificam como tradição inventada.O nacionalismo, os símbolos nacionais e as interpretações históricas são caracterizados por Hobsbawm e Ranger (1984) como indispensáveis na compreensão da leitura do contexto e das atividades ligadas aos discursos cívicos. "A escola [...] era a instituição fundamental criada pela nação para formar o cidadão". (BITTENCOURT, 2009, p. 56). Se até a década de 1970, o civismo cumpria a função de imprimir também uma moral, um sentimento pátrio, como recorda Gersy, na atualidade, diante das fragilidades que a política pública deflagra cotidianamente cabe a seguinte interrogação : seria o sentimento nacionalista ainda responsável por agregar crianças, jovens e pais em torno dessa festa cívica? 


\section{BIBLIOGRAFIA}

ALMEIDA, Dóris Bittencourt. Vozes Esquecidas em Horizontes Rurais : histórias de professores. 2001. 245 f. Dissertação (Mestrado em Educação) - Programa de Pós-Graduação da Faculdade de Educação, Universidade Federal do Rio Grande do Sul, Porto Alegre, RS, 2001.

ALMEIDA, Dóris Bittencourt. Memórias da Rural : narrativas da experiência educativa de uma escola normal rural pública (1950-1960). 2007. 272 f. Tese (Doutorado em Educação) - Programa de Pós-Graduação da Faculdade de Educação, Universidade Federal do Rio Grande do Sul, Porto Alegre, RS, 2007.

ARENDT, Isabel. Educação, Religião e Identidade Étnica : o Allgemeine Lehrerzeitung e a escola evangélica no Rio Grande do Sul. São Leopoldo : Oikos, 2008.

ARROYO, M. Educação para novas relações de trabalho no campo. In: SEMINÁRIO NACIONAL DE ESTUDOS E PESQUISAS EDUCACIONAIS. Anais do Seminário : educação no meio rural. Brasília : INEP, 1983.

BASTOS, Maria Helena Camara ; LEMOS, Elizandra Ambrosio ; BUSNELLO e Fernanda. A pedagogia da ilustração : uma face do impresso. In: BENCOSTTA, Marcus Levy Albino. Culturas Escolares, Saberes, Práticas Educativas : itinerários históricos. São Paulo : Cortez, 2007, pp. 41-78.

BENCOSTA, Marcus Levy Albino. Grupos escolares no Brasil : um novo modelo de escola primária. In : STEPHNOU, Maria ; BASTOS, Maria Helena Camara. Histórias e Memórias da Educação no Brasil : século XX. Petrópolis, RJ : Vozes, 2009. v. 3, pp. 68-77.

BHABHA, Homi K. O Local da Cultura. Belo Horizonte : Ed. UFMG, 1998.BITTENCOURT, Circe Maria Fernandes. As Tradições Nacionais e o Ritual das Festas Cívicas. In PINSKY, Jaime (Org.) O Ensino de História e a Criação do Fato. São Paulo : Contexto, 2009, pp. 53-92.

BHABHA, Homi K. Identidade nacional e ensino de história do Brasil. In KARNAL, Leandro (Org.) História na Sala de Aula. 3ª. ed. São Paulo : Contexto, 2005, pp. 185-204.

BRASIL. Lei Federal no. 9093, de 12 de setembro de 1995. Dispõe sobre feriados. Brasil, Brasília, 1995.

BRASIL.. Lei Federal ํo 10.607, de 19 de dezembro de 2002. Dá nova redação ao art. $1^{\circ}$ da Lei ํo 662, de 6 de abril de 1949. Brasil, Brasília, 2002.

BRITTO, Lenir Marina Trindade de Sá. O Fechamento das Escolas Rurais : a lógica dos sobreviventes no campo. 2007. 124 f. Trabalho de Conclusão de Curso (Pedagogia - Licenciatura) Curso de Pedagogia - Ênfase em Séries Iniciais, Universidade do Vale do Rio dos Sinos, São Leopoldo, RS, 2007.

BURKE, Peter (Org.). A Escrita da História : novas perspectivas. São Paulo : Editora UNESP, 1992.

CARVALHO, Jose Murilo de. A Formação das Almas : O imaginário da República no Brasil. Companhia das Letras : São Paulo, 2011.

CERTAU, Michel de ; GIARD, Luce e MAYOL, Pierre. A Invenção do Cotidiano : morar, cozinhar. 10. ed. Tradução de Ephraim Ferreira Alves. Petrópolis, RJ : Vozes, 2011.

CHARTIER, Roger. À Beira da Falésia : a história entre incertezas e inquietude/trad. RAMOS, Patrícia Chittoni, Porto Alegre : Ed. Universidade/UFRGS, 2002. 
CUNHA, Maria Tereza Santos. Saberes impressos escritas da civilidade e impressos educacionais. (Década de 1930 a 1960). In: YAZBECK, Carolina ; ROCHA, Marlos Bessa Mendes da. (Orgs.). Cultura e História da Educação : intelectuais, legislação, cultura escolar e imprensa, Juiz de Fora : Editora UFJF, 2009, pp. 233-251.

CURY, Carlos Roberto Jamil. A educação nas constituições brasileiras. In : STEPHANOU, Maria ; BASTOS, Maria Helena Câmara. (Org.). Histórias e Memórias da Educação no Brasil. Petrópolis, RJ : Vozes, 2009. v. 3, pp. 17-29.

DREHER, Martin Norberto. Breve História do Ensino Privado Gaúcho. São Leopoldo : Oikos, 2008.

DREHER, Martin Norberto. Igreja e Germanidade. São Leopoldo : Sinodal, 1984.

FERRI, Cássia. Classes Multisseriadas : que espaço escolar é esse ? 1994. 161 f. Dissertação (Mestrado em Educação) - Programa de Pós-Graduação em Educação, Universidade Federal de Santa Catarina, Santa Catarina, SC,1994.

FISCHER, Beatriz Terezinha Daudt. Professoras : histórias e discursos de um passado presente. Pelotas : Seiva, 2005.

GERTZ, René. O Estado Novo no Rio Grande do Sul. Passo Fundo : Editora da Universidade de Passo Fundo, 2005.

GHIRARDELLI JUNIOR, Paulo. História da Educação. São Paulo : Cortez, 2009.

HALBWACHS, Maurice. A Memória Coletiva. São Paulo : Ed. Centauro, 2006.

HOBSBAWAM, Eric. Era dos Extremos : o breve século XX - 1914-1991. São Paulo : Companhia das Letras, 2000. . RANGER, Terence (Orgs.). A Invenção das Tradições. Rio de Janeiro : Paz e Terra, 1984.

KREUTZ, Lúcio. Escolas comunitárias de imigrantes no Brasil : instâncias de coordenação e estruturas de apoio. Revista Brasileira de Educação, Rio de Janeiro, v. 1, n. 15, 2001, pp. 159-177.

LOPES, Antônio de Pádua Carvalho. A escola em festa : as festividades escolares na Primeira República no Piauí. In : VI CONGRESSO LUSO BRASILEIRO DE HISTÓRIA DA EDUCAÇÃO. Uberlândia/MG : COLUBHE 06, 2006.

MARTINS, Rodrigo Perla. A Produção Calçadista em Novo Hamburgo e no Vale do Rio dos Sinos na Industrialização Brasileira : exportação, inserção comercial e política externa : 1969-1979 / 2011. 198 f. Tese (Doutorado em História), Pontifícia Universidade Católica do Rio Grande do Sul, Porto Alegre, RS, 2011.

MICELI, Paulo. O Mito do Herói Nacional. 4⿳a . ed. São Paulo : Contexto, 1994.

MIGUEL, Maria Elisabeth Blanck. As escolas rurais e a formação de professores : a experiência do Paraná - 1946-1961. In : WERLE, Flávia Obino Corrêa (Org.). Educação Rural em Perspectiva Internacional : instituições, práticas e formação do professor. Ijuí : Ed. Unijuí, 2007. pp. 79-99.

MONARCHA, Carlos (Org.). História da Educação Brasileira : formação do campo. 2. ed. ampl. Ijuí : Ed. Unijuí, 2005.

NORA, Pierre. Entre Memória e História : a problemática dos lugares. 10 ed. São Paulo : Educ, 1993.

PESAVENTO, Sandra Jathay. Introdução. In : PESAVENTO, Sandra Jathay ; SANTOS, Nádia Maria Weber ; ROSSINI, Miriam de Souza. Narrativas, Imagens e Práticas Sociais : percursos em história cultural. Porto Alegre, RS : Asterisco, 2008, pp. 11-19.

PESAVENTO, Sandra Jathay. História \& História Cultural. 2. ed. Belo Horizonte : Autêntica, 2004. 
PIMENTEL, Alessandra. O método da análise documental : seu uso numa pesquisa historiográfica. Cadernos de Pesquisa, São Paulo, n. 114, pp.179-195, nov. 2001.

SAVIANI, Dermeval. A política educacional no Brasil. In : STHEFANOU, Maria e BASTOS, Maria Helena Câmara (orgs). Histórias e Memórias da Educação no Brasil. Vol III : século XX. Petrópolis : Editora Vozes, 2005.

SCHEMES, Claudia. Pedro Adams Filho : empreendedorismo, indústria calçadista e emancipação de Novo Hamburgo (1901-1935). 2006. 446 f. Tese (Doutorado em História), Pontifícia Universidade Católica do Rio Grande do Sul, Porto Alegre, RS, 2006.

Schütz, Liene Maria Martins. Os Bairros de Novo Hamburgo. Novo Hamburgo, 2001.

SELBACH, Jéferson Francisco. Novo Hamburgo 1927-1997 : os espaços de sociabilidade na gangorra da modernidade. 1999. 370 f. Dissertação (Mestrado em Arquitetura e Urbanismo) Programa de Pós-Graduação em Planejamento Urbano e Regional, Universidade Federal do Rio Grande do Sul, Porto Alegre, RS, 1999.

SOUZA, José Edimar de. Memórias de Professores : histórias de ensino em Novo Hamburgo/RS (1940-2009). Porto Alegre : Evangraf, 2012.

STRUJAK, Ana Paula ; ZANLORENZI, Claudia Maria Petchak. Desfiles escolares e a legitimação do civismo em Irati. In IX SEMINÁRIO NACIONAL DE ESTUDOS E PESQUISAS “HISTÓRIA, SOCIEDADE E EDUCAÇÃO NO BRASIL”. Universidade Federal da Paraíba, João Pessoa - 31/07 a 03/08/2012 Anais Eletrônicos - ISBN 978-85-7745-551-5, pp. 2197- 2206.

TEDESCO, João Carlos (org.). Usos de memórias : política, educação e identidade. Passo Fundo : UPF, $2002, \mathrm{~s} / \mathrm{d}$.

THOMPSON, Paul. A Voz do Passado : Historia Oral. Rio de Janeiro : Paz e Terra, 1992.

THUM, Carmo. Educação, História e Memória : silêncios e reinvenções pomeranas na Serra dos Tapes. 2009. 383 f. Tese (Doutorado em Educação). Programa de Pós-Graduação em Educação. Universidade do Vale do Rio dos Sinos, São Leopoldo, RS, 2009.

TRIVIÑOS, Augusto Nibaldo Silva ; NETO, Vicente Molina ; GIL, Juana Maira Sancho et al. A Pesquisa Qualitativa na Educação Física : alternativas metodológicas - $2^{\mathrm{a}}$ ed. - Porto Alegre : Editora da UFRGS, Sulina, 2004.

VAZ, Aline Choucair. As festividades cívicas nas escolas mineiras e o $1^{\circ}$ de maio (1930-1954). In IX SEMINÁRIO NACIONAL DE ESTUDOS E PESQUISAS “HISTÓRIA, SOCIEDADE E EDUCAÇÃO NO BRASIL”. Universidade Federal da Paraíba - João Pessoa - 31/07 a 03/08/2012 - Anais Eletrônicos - ISBN 978-85-7745-551-5, pp. 2699 - 2721.

VECCHIA, Marisa V. Formolo Dalla ; HERÉDIA, Vânia B. M. e RAMOS, Felisbela. Contradições no sistema de educação : uma releitura acerca da expansão da rede municipal de ensino em Caxias do Sul. Métis : história \& cultura, Caxias do Sul, v. 7, n.14, pp. 21-37, jul./dez. 2008.

VEIGA, Cynthia Greive ; GOUVEA, Maria Cristina Soares. Comemorar a infância, celebrar qual criança ? Festejos comemorativos nas primeiras décadas republicanas. In: Educação e Pesquisa. São Paulo, v. 26, n. 01, jan/jul, 2000.WERLE, Flávia Obino Corrêa ; METZLER, Ana Maria Carvalho. En busca de Contenidos y Sentidos para La Educación Rural. In: GONZÁLEZ PÉREZ, Teresa; LÓPEZ, Oresta (Coord.). Educación Rural en Iberoamérica: experiencia histórica y construcción de sentido. [S.1.] : Anroart - Ediciones, 2009. pp. 79-109.

VEIGA, Cynthia Greive ; GOUVEA, Maria Cristina Soares et al. Escola Normal Rural La Salle na Voz dos Ex-Alunos : sentidos e apropriações. In: WERLE, Flávia Obino Corrêa (org.). Educação Rural em Perspectiva Internacional : instituições, práticas e formação do professor. Ijuí : Ed. UNIJUí, 2007. 
VEIGA, Cynthia Greive ; GOUVEA, Maria Cristina Soares et al.. Constituição do Ministério da Educação e Articulação entre os níveis federal, estadual e municipal da educação. In: STEPHANOU, Maria ; BASTOS, Maria Helena Camara (Org.). Histórias e Memórias da Educação no Brasil : século XX. Petrópolis, RJ : Vozes, 2009. v. 3, pp. 39-53.

DOCUMENTOSDocumento 1 : NOVO HAMBURGO. Decreto № 06, de $1^{\circ}$ de junho de 1939.

Documento 2 : MINHA Despedida. Maria Gersy H. Thiesen. Livro de Visita de Autoridades da EMEF Castro Alves. Localizado, em 2010, no arquivo passivo desta instituição. Abertura do livro em março de 1953 e último registro em maio de 2001.

\section{NOTAS}

1. Para Bittencourt (2009) pátria representa a família amplificada. E a família, devidamente constituída, tem por elementos orgânicos a honra, a disciplina, a fidelidade, a benquerença, o sacrifício. Pátria, do latim 'patriota', terra paterna, indica a terra natal ou adotiva, pela qual, os sujeitos constituem elos e vínculos afetivos, culturais, valores e produzem história.

2. Denomina-se Independência do Brasil o processo que culminou com a emancipação política do nosso país do reino de Portugal, no início do século XIX. Oficialmente, a data adotada é 7 de setembro de 1822, quando ocorreu o episódio do chamado Grito do Ipiranga. Segundo a história oficial, às margens do riacho Ipiranga, hoje de São Paulo, o Príncipe Regente D. Pedro, bradou perante a sua comitiva : Independência ou Morte. (MICELI, 1994).

3. Foram realizadas duas entrevistas, além de três encontros informais. Cada entrevista registra duas horas de gravação. Optou-se pela identificação dos sujeitos conforme termos de consentimentos assinados.

4. O documento localizado enfatiza a criação de escolas públicas em Novo Hamburgo bem como a diminuição das matrículas das escolas particulares. Utiliza-se ainda a justificativa cívica nacional para atender uma demanda local. "Considerando que essa obra notável de civismo se desenvolve no território pátrio, onde, de 7.500 .000 creanças em idade escolar, estão matriculadas nas escolas públicas e particulares apenas 2.5000.000. [...] está despertando nas classes populares, por meio de propaganda hábil, uma mentalidade patriótica [...] condição fundamental de soberania nacional ; [...] é coordenado pelo eminente brasileiro Dr. Gustavo Armbrust." (Documento 1 : Decreto № 06 de $1^{\circ}$ de junho de 1939). Denomina Escola Domiciliar № 1 "Dr. Gustavo Armbrust" aula de alfabetização, localizada na zona rural deste município denominada de "Wiesental". 0 local popularmente chamado, na época, pelos "brasileiros", de "Visital". Atualmente, denominase a região de limite entre os bairros Rondônia e Canudos, em direção à estrada da Feitoria, São Leopoldo. Para Selbach (1999), na década de 1950 também foi denominada de área suburbana. A denominação da escola atende uma prática da época, de que os estabelecimentos escolares recebessem nomes de personalidades patronímias ligados ao desenvolvimento educacional no país.

5. Atualmente bairro Feitoria, situada nas imediações de Lomba Grande, utilizada por muitos habitantes para realização de práticas cotidianas, em virtude da proximidade e facilidade de transporte. Até 1940, Lomba Grande incorporava-se a este espaço considerando o fato de ser $6^{\circ}$ Distrito de São Leopoldo, criado a partir do Ato Municipal no 39 de 1904. Apenas em 1940 essa área de terras passou ao perímetro municipal de Novo Hamburgo. (SCHÜLTZ, 2001).

6. Dreher (2008) ; Arendt (2008) e Kreutz (2001) sugerem a tríade (Igreja, Escola e Cemitério) aspecto que figurava cenários das comunidades germânicas instaladas em diferentes partes do Brasil (séc. XIX). Os caminhos abertos pelos imigrantes originaram lugares. A construção de uma cultura local dava-se pela abertura das picadas que prepararam espaço da convivência cotidiana. Arendt (2008) identifica esta forma original de escola como "Kolonieschulen" - Escolas rurais. 
7. Os grupos escolares que compreendessem mais de 200 alunos passariam à categoria de Colégios. A criação dos grupos escolares pelo estado não garantia que ele construísse o prédio.

8. O Vale dos Sinos compreende um conjunto de municípios do Rio Grande do Sul cujo nome se dá pela disposição física/hidrográfica beneficiados pelas águas do Rio dos Sinos. No final do século XIX, o professor José Afonso Höher seguia o ritmo itinerante da docência, percorria as localidades de Lomba Grande e arredores como (Taquara, Gravataí, Sapiranga) levando conhecimento para o interior. Gersy lembra que o pai ficava afastado semanas e percorria diferentes caminhos à cavalo ; inicia a entrevista contando histórias destes lugares que o pai costumava "trazer".

\section{RESUMOS}

A investigação desenvolvida objetiva compreender, a partir das memórias de duas professoras, principalmente as que remetem ao Desfile da Pátria, como o nacionalismo cívico foi cultuado no espaço rural em Novo Hamburgo/RS. A pesquisa desenvolvida sob a perspectiva da História Cultural utiliza a metodologia da História Oral e vale-se de entrevistas semiestruturadas tendo narrativas e imagens como documentos. Analisa memórias de práticas que possibilitaram recompor cenários de contexto identificando marcas cívicas de uma época, como respeito e amor à pátria. $O$ arraigamento à cultura local também representou um conjunto de significados partilhados e construídos para conhecer um pouco sobre como a ideia de nação foi, pela prática pedagógica da escola, dirimindo o sentimento de colonização em favor da brasilidade.

Les recherches menées visent à comprendre comment le nationalisme civique a été adopté dans les régions rurales Novo Hamburgo/RS, à partir des mémoires de deux enseignants, en particulier celles qui se réfèrent à la Parade de la Patrie. La recherche développée à partir de la perspective de l'histoire culturelle utilise la méthodologie de l'histoire orale, avec des entrevues semi-structurées, des récits, des documents et des images. L'analyse des souvenirs de pratiques discerne les marques d'identification d'une époque civique, comme le respect et l'amour de la patrie. L'enracinement de la culture locale venait également d'un ensemble de significations partagées et construites // autour de l'idée de nation, dans un processus pédagogique intégrant le sentiment de la colonisation en faveur de Brazilianness

\section{ÍNDICE}

Palavras-chave: festa da Pátria, memória, nacionalismo brasileiro, educação rural, prática pedagógica

Mots-clés: parti de la patrie, mémoire, le nationalisme brésilien, l'éducation rurale, les pratiques pédagogiques 


\section{AUTOR}

\section{JOSÉ EDIMAR DE SOUZA}

Doutorando em Educação na UNISINOS/Brasil com bolsa CAPES/ProexEspecialista em Educação na Fundação Escola Técnica Liberato S. V. da Cunha

profedimar[at]gmail.com 